Whitworth Digital Commons

Whitworth University

English Faculty Scholarship

English

2013

\title{
"It's Good to Be Shifty": The Local Democracies of Old Southwestern Humor
}

D. Berton Emerson

Whitworth University, dbemerson@whitworth.edu

Follow this and additional works at: http:// digitalcommons.whitworth.edu/englishfaculty

Part of the English Language and Literature Commons

\section{Recommended Citation}

Emerson, D. Berton. " 'It’s Good to Be Shifty': The Local Democracies of Old Southwestern Humor." American Literature, vol. 85, no. 2, 2013, pp. 273-301. DOI: 10.1215/00029831-2079161.

This Peer Reviewed Article is brought to you for free and open access by the English at Whitworth University. It has been accepted for inclusion in English Faculty Scholarship by an authorized administrator of Whitworth University. 


\title{
“It's Good to Be Shifty": The Local Democracies of Old Southwestern Humor
}

\author{
D. Berton Emerson
}

Midway through Johnson Jones Hooper's Some Adventures of Captain Simon Suggs (1845), the narrative declares its arrival at the "most important moment in the history of our hero," but then digresses, issuing the following apology:

And we beg the reader to believe, that we approach this portion of our subject with a profound regret at our own incapacity for its proper illumination. Would that thy pen, O! Kendall were ours! Then would thy hero and ours - the nation's Jackson and the country's Suggs — go down to far posterity, equal in fame and honors, as in deeds! But so the immortal gods have not decreed! Not to Suggs was Amos given! Aye, jealous of his mighty feats, the thundering Jove denied an historian worthy of his puissance! Would that, like Caesar, he could write himself! Then, indeed, should Harvard yield him honors, and his country-justice!

In the next sentence, the narrative changes tone: "Early in May of the year of grace-and excessive bank issues - 1836, the Creek war was discovered to have broken out." In this compressed introduction to a fictionalized episode set during an actual historical war, the narrative makes a number of allusions to national politics: Andrew Jackson and his campaign biographer Amos Kendall; Jackson's honorary degree from Harvard; Jackson's political war on the US Bank; and the controversial issues of Indian removal and land redistribution. On the face of it, such references glorify Jackson while associating Simon Suggs and his humble aspirations to be county sheriff with the great nineteenth-century symbol of popular democracy. The ironic, 
even mocking tone, however, suggests that these allusions might take aim at something other than the would-be sheriff's provincialism. Instead, the mock-epic conceit highlights the gaps between local and national scales of reference. Rather than neatly fitting into the national framework evoked by the allusion to Jackson, this passage distinguishes between local instances of direct democratic politics and national narratives of a homogeneous imagined community united through representative, procedural government and abstracting cultural forms. The tale that follows explores the possibility of a local sociality working out power relations outside the legal, judicial, and executive maneuverings of the US nation. Unyoked from the nation and its norms, these local episodes - along with others in the Southwestern humor tradition-yield an unexpected trove of alternative democratic positions in the mid-nineteenth century. ${ }^{2}$

From a variety of perspectives, literary criticism has typically read these antebellum frontier sketches as contributing to national consolidation through print culture. Well-educated, Whig-leaning professionals crafted their humorous tales with the help of a narrative framing device - what Kenneth Lynn characterized as a cordon sanitaire - to warn the rest of the country of the dangers of democratic excesses associated with the rise of Jacksonian democracy. ${ }^{3}$ Emerging amidst the transportation, communications, and market revolutions, Southwestern humor circulated widely in newspapers across the country, most famously in William T. Porter's New York-based Spirit of the Times. ${ }^{4}$ In some cases, these regionalist texts—particularly those that most emphatically employ the framed narrative-supplemented the development of homogeneous (white, male, genteel) national identifications. ${ }^{5}$ As the mock-epic conceit of Simon Suggs shows, however, examples of Southwestern humor just as often reveal the inadequacy of national models of republican democracy for making sense of diverse communities negotiating power relations on their own terms. Instead, these texts frequently portray localized sites in 
which politically conscious socialities both remain largely unregulated by the nation and its virtual forms of governance and engage in more immediate experiments with local democratic rule.

This essay thus explores the tension between different scales of identificationspecifically the local and the national—played out in the fictive archives of Southwestern humor with special attention to the play of democratic decision-making. Local and populist-oriented politics have received increasing critical attention in recent years, particularly from historians of the early national period who have uncovered a wider range of voices in debates over the meanings of popular governance. ${ }^{6}$ Few studies, however, have taken a sustained look into midnineteenth-century print culture. Such a task is daunting given the near-realization of universal white male suffrage along with the increasingly national mobilization of political parties during this period. ${ }^{7}$ Moreover, as Trish Loughran has convincingly argued, the material developments fostering US nation building in this period effectively rechanneled local voices into broader, more streamlined communities. According to Loughran, the initial formation of the US nation under Federalist ideology depended upon the dislocation and disjunction of various localities over vast space; however, from the 1820 s onward, "the more connected regions appeared to be (in print), the more regionalized (rather than nationalized) their identities became.... A growing sense of simultaneity, in other words, produced not nationalism but an ever more entrenched sectionalism." 8

Whether we characterize the antebellum period as one of increasingly entrenched sectionalism, as Loughran contends, or as one of many competing nationalisms, as Coleman Hutchison and Robert Levine have suggested, print culture has been understood as an important component in fostering identifications with a national community. ${ }^{9}$ Those identifications, in turn, 
remove decision making from the local level and relocate it at an abstracted remove, placing it in the hands of the few representing the interests of the nation. In this lies a conceptual problem. As Dana Nelson has argued, the US nation—particularly in its Constitutional formulation—has severely constrained the democratic imaginary, largely because "the Constitution created a new, abstracted, and antipolitical national identity that worked to sublate what it cast as the confusions, unpredictability, and inefficiency of local democracy." As a result, "the Constitutional nation persistently draws our attention toward its containment promise, its promise to manage democracy for us." ${ }^{10}$ In this way, it becomes increasingly difficult to imagine politics on any scale other than the national and through any form other than the deferral of decision-making via the indirect democracy of electoral, representative government. This essay addresses this challenge by recalibrating our discussion of scale to illuminate oversights resulting from the critical hegemony of the nation-form, specifically by reevaluating material that has been designated—and disparaged—as local. ${ }^{11}$

Most nation-oriented readings portray the humor of the Old Southwest either as regional subset supplementing nationalization or as reactionary polemics rejecting the impingements of nation, market capitalism, urbanization, or modernity. This essay, instead, reads these fictions in terms of locality and with special attention to their articulations of alternative democratic socialities. These socialities, I argue, evidence local decision-making existing alongside or outside the abstracting, normalizing tendencies of elitist republican ideology; they are unreceptive to traditional social hierarchies and civic institutions that supplement the Constitutionally-managed nation-state; and they often engage in a more radical version of democracy characterized by dialogical negotiations in immediate spaces and temporalities. Unlike the national republic defined by Constitutional management and procedural makeup, 
these stories present a version of democracy that, as Christopher Castiglia characterizes it, appears in “citizens' capacity to organize themselves for collaborative negotiation and public action to rectify injustice and improve associational life in ways that take account of divergent expectations and experiences." ${ }^{12}$ Messy and unrefined, these negotiations often take place in a two-step operation I call democratic play: using various literary strategies, the narrative establishes (and often celebrates) a local sociality largely detached from national political structures, which then makes it possible for individuals to participate directly in decision making outside of any predetermined rules or hierarchies.

Under these terms, this essay revisits episodes from three well-known examples of Southwestern humor: Hooper's Simon Suggs, Augustus Baldwin Longstreet's Georgia Scenes (1835), and George Washington Harris's Sut Lovingood: Yarns Spun by a Durn'd Fool (1867). The first of the three to appear, Georgia Scenes most forcefully attempts to tame its subject matter by placing it within a national framework. This attempt reveals an anxiety over - as well as a fascination with - the rabble's uncouth ways and their possible ascendance to fully authorized political subjects. Despite the narrative's efforts at containing this possibility, Longstreet's text repeatedly reveals the fissures between a national model of deference to abstract reason and its implementation in local communities. To an even greater extent, Simon Suggs and Sut Lovingood portray socialities in which the structures of nation-legal, political, and cultural—constrain the lives and political decision making of local inhabitants in only limited ways. Hooper's narrative, animated by elements of the carnivalesque and anti-official play, registers the most fully developed faith in alternative democratic socialities operating on their own terms of democratic play. Conversely, Harris's postbellum collection reveals that exploding hierarchies and leveling the social ground-perhaps the most innovative of the 
tradition in its implementation of tropes enacting Deleuzean notions of becoming-animal—does not inevitably produce a more democratic society. Providing a spectrum of possibilities explored by Southwestern humor as a whole, these narratives, to different extents and with different valuations, explore forms of resistance to national frameworks, offering sensitive registers of the dynamics and contingencies of mid-nineteenth-century democracy and locality.

\section{NATIONAL IMPOSITIONS AND DEMOCRATIC PLAY}

Credited with initiating the tradition, Longstreet's Georgia Scenes places its depiction of local color within a narrative of national homogenization; however, despite its apparent endorsement of national rules of decorum and socio-political deference, the collection repeatedly reveals ways that the local exceeds or escapes the national norms generated by Constitutional representative democracy and civic institutions. At first glance, the sketches seem apolitical, primarily aimed at entertainment and perhaps the preservation of a particular time and place. Longstreet apparently thought so. In a letter composed shortly after the collection's publication, he wrote of his desire to fill "a chasm in history which has always been overlooked — the manners, customs, amusements, wit, dialect, as they appear in all grades of society.... [For] who ever tells us of the comments and the wits and the ways of the common walks of life ...? ${ }^{\prime 13}$ In answer to his own question, Longstreet proffers Georgia Scenes as an attempt to rescue local culture from the historical dustbin. Yet throughout the scenes, Longstreet betrays his own discomfort with his subject matter, apologizing for violence, uncouth manners and mannerisms, and unrefined language in a series of authorial intrusions. This conflict between heavy-handed didacticism and a professed desire to accurately represent the often distasteful local folkways appears as early as the preface of the first edition. After celebrating his cast of characters, Longstreet concludes the 
preface with an apology to "those who have taken exceptions to the coarse, inelegant, and sometimes ungrammatical language, which the writer represents himself as occasionally using, that it is language accommodated to the capacity of the person to whom he represents himself as speaking." ${ }^{14}$ Longstreet no doubt knew that linguistic offenses were the least of it, that readers would most likely take exception to the characters and their rude behavior.

Longstreet's apology thus suggests his attempts to play a mediating role. If he seeks pardon for the rawness of his characters, he also seems eager to intervene on behalf of a way of life and a population incapable of representing itself. Such a narrative strategy mimics the containment style of the Constitution, which rhetorically assents to the ideals of individual autonomy while rerouting political agency from individuals to elected representatives. The key term here - twice repeated in Longstreet's phrasing — is represents. Like other cultural and political representatives, elected or self-nominated, working within the Constitutional framework, Longstreet, through his two narrators, wishes to represent a local community to the nation, to speak for the local in such a way that it can participate within a national culture. ${ }^{15}$ Through the medium of print in transregional publications, Longstreet-as-representative softens the rough edges of his characters as a demonstration of the degree to which his region can be part of the national picture. Even as the author might esteem this version of the plain folk as important symbols for the nation — as virtuous yeomen of the republic - he shows little confidence in their qualifications to speak for themselves or to act as fully authorized participants in the political realm. His characters, however, have other ideas.

Longstreet's strategy becomes clear in the opening scene, "Georgia Theatrics," in which the narrator Lyman Hall recalls a morning ride two decades earlier through the "Dark Corner" of Lincoln County. Hall's ride through the beautiful but morally compromised locale is disrupted 
by noises suggesting a vicious altercation. Determined to impose order, Hall hurries to the scene, yet arrives only to find a single person. Without any greeting, a flummoxed youth rebukes Hall: 'You needn't kick before you're spurr'd. There a'nt nobody there, nor ha'nt been nother. I was jist seein' how I could 'a' fout" $(G S, 11)$. Mistaking a theatrical performance for a brawl, Hall ends up humbled, made the butt—or horse's ass—of the joke. Hall frames his embarrassment, though, by reassuring readers that in the two decades since his ride, the Dark Corner has changed "from vice and folly to [a site of] virtue and holiness" (GS, 9). While Hall may not have succeeded in imposing decorum upon the local in this scene, some agent has. Four scenes later, "The Fight" suggests what has wrought these changes. After describing the events of an otherwise good-natured fight between the two "best men" of the county, Hall delivers a closing monologue that echoes his earlier assurances: "Thanks to the Christian religion, to schools, colleges, and benevolent associations, such scenes of barbarism and cruelty as that which I have just been describing are now ... rare" (GS, 64). The narrative's reference to these types of disciplinary institutions points to what Castiglia identifies as an increasingly pervasive "discourse of institutionalism" that limited this era's democratic imaginary. ${ }^{16}$ Playing a complementary role to the Constitution's containment of democracy, institutions such as churches, schools, and reform societies imposed social norms on local customs, providing a key supplement for national management and homogenization. In these, Longstreet and his narrative find valuable allies.

What should not go unremarked is the youth's rebuttal. As much as the narrative seems to impose national standards on its subjects, the local social practices it represents often remain intransigent - if not oblivious - to those standards. The characters in these and other sketches seem either ignorant of or resistant to the oversight of the intrusive narrator. In "The Dance," the 
sophisticated narrator — this time Baldwin—returns to the community of his youth and attends a dance at the home of a local magistrate. Early in the tale, Baldwin's articulate (and condescending) narration highlights the contrast between the local particularities and what heand his presumably national readership —-would take as the norms for such an occasion. $\mathrm{He}$ details differences between the plain dresses of the "country girls" and those worn by the young women of "our republican cities." Further distinctions include the manner of greeting—instead of "the custom of kissing," the folk use "a hearty shake of the hand and smiling countenances"and the lack of social rules- "Here were no formal introductions to be given, no drawing for places or partners, no parade of managers, no ceremonies. It was perfectly understood that all were invited to dance" (GS,14-15). Baldwin thus accentuates the deviations from cosmopolitan social conventions to share an inside joke with his national readership. To some degree, he pokes fun at both versions, but his bias for the more sophisticated version is clear. Oblivious to their social offenses, however, the locals merrily proceed with their dance.

Soon enough, Baldwin's narrative registers greater ambivalence both toward the high society he now claims as his own and the more rustic culture of his youth. No longer willing to sit back and comment, he seeks common ground with the local community after discovering the presence of an old sweetheart, who has happened to marry the squire. When he asks to be reacquainted with his former love, he assures his host, “don't get jealous, squire, if she seems a little too glad to see me." To his overconfident guest, the squire responds, "No danger ... she hadn't seen me then, or she never could have loved such a hard-favoured man as you" $(G S, 16)$. Subsequently, his former sweetheart fails to recognize his name. Name-dropping and old dance moves also fail to spark her memory. Embarrassed, he retreats as the party continues on into the night. The sketch closes with the last words of a letter, in which the squire informs Baldwin, 
"Since you left here, [my wife] has been thinking about old times, and she says, to save her life, she can't recollect you" $(G S, 22)$. Upon his arrival at the dance, Baldwin enters certain of his cultural sophistication and social superiority. He comes prepared to represent his old community and to explain the peculiarities of local culture to readers whom the narrative implies share his urban sophistication. Yet his perspective and his new social prejudice do not align seamlessly with the associational life of this community, and he again becomes the butt of the joke. His old acquaintances show no interest in a representative who might translate their local customs into the national idiom, and theirs is the last word.

While there is little in this tale to suggest political action, it begins to sketch the foundations of what I have called democratic play — a local sociality less invested in a logic of representation implied in indirect, procedurally representative democracy than working out the contours of social interaction on their own terms. Even when the narrative would most like to manage any excess, the tension between national impositions (Longstreet's prerogative) and alternative democratic socialities_ — neither resisting nor embracing, just functioning autonomously_remains unresolved. In “The Turn Out,” for instance, Lyman Hall relates a 1790 visit to an old friend named Captain Griffin. The featured event of this visit involves Hall's and Griffin's observation of a schoolboy rebellion against a tyrannous schoolmaster. The low-stakes rebellion - the students demand a week-long vacation - is politically encoded, punctuated by allusions to the American Revolution. When the schoolmaster gains the upper hand, Captain Griffin cries out to the boys to remember General Washington, whose name instantly "cured their wounds and dried up their tears." On the surface, the evocation of the national father galvanizes the boys' rebellion, and they renew their battle, gaining the assurance of a one-day holiday from their teacher. When the democratically inclined boys demand a week, they appear 
ready to win. Again, though, the national symbol intervenes, and Captain Griffin, "after the common but often unjust custom of arbitrators, split the difference" $(G S, 81)$. Hall endorses the revolutionary spirit, but waxes ambivalently between the assurance of constraint and the recognition of injustice in this type of arbitration. Captain Griffin, as the representative embodied heir of Washington, stands present in order to serve as arbiter imposing order in the face of the budding democracy. Even so, the boys do win their holiday.

The final scene, "The Shooting Match," appears to resolve the tension between local determination and national standards when Hall reasserts himself as virtual representative of a ragtag sociality. At the close of what has been a tale of social leveling-Hall finds common ground with a group of backwoods countrymen after finishing second in a shooting contestHall refuses his prize, raising suspicion about his intentions. He assures the crowd that he has no ulterior motive, is "not a candidate for anything." Yet Hall's declaration effectively reminds both the crowd and his readers of the representative nature of managed democracy and the republican ideal that the best should rule. In response, one character seems to accede to that ideal when he declares, "If ever you come out for anything, Lyman, jist let the boys of Upper Hogthief know it, and they'll go for you to the hilt" $(G S, 214)$. Such statements work on two levels. They fulfill Longstreet's stated objective in the preface, that he would record the "comments of the wits and ways of the common walks of life." Yet they also reestablish national principles of political containment —in this instance ventriloquized through a commoner — and reinstitute order to what the author presumes to be an excessively unruly scene. As the concluding scene, Longstreet's national imposition in effect gets the final word.

It is this idea of the "final-word" that directs most readings of this tradition, or at least those that choose the nation as the conceptual point of departure. Yet imposing a conventional 
narrative structure on the entire collection of Georgia Scenes is as problematic as assuming that the frame successfully circumscribes and manages the excesses of these local socialities. ${ }^{17}$ Reading these tales in terms of locality, however, resists such structuring devices and insists on the narrative resistance (or counternarrative) that these local communities present to a cultural and political elite. The flummoxed youth wittily rebuking Hall's unwarranted imposition, for example; the dance-goers ignoring the obligations of deference; the boys winning their holiday. Reading for locality also reveals how Longstreet's narrative mediates local and national, resisting the national ideological hegemony that literary critics often assume. Even as it seeks containment in the terms of the cordon sanitaire, the nation-oriented narrative becomes a suturing device that makes the seams between the nation and the local all the more visible. As my readings of Georgia Scenes suggest, the plausibility of democratic play persists in spite of the author's attempted constraints. And this persistence makes alternative democratic sociality a more viable political option when juxtaposed with other examples that consider national management infeasible or wholly unnecessary.

\section{DEMOCRATIC PLAY AND THE VIRTUE OF SHIFTINESS}

With the national tumult produced in an era of Indian removal, rampant land speculation, political corruption, and rapid immigration, the still unsettled Alabama offered a different cultural ethos from Longstreet's Georgia. Hooper's mid-twentieth-century biographer describes it this way: "And so it came to pass, for all his homespun jeans, his rawhide galluses and his bare feet a man was accepted for what he was, not what he had been, and no questions raised. It might have been frontier etiquette to ask a settler whence or even how he came to Alabama- but never why." ${ }^{18}$ Amidst this environment, Hooper planted one of the most memorable characters of the 
Southwestern humor tradition, a man who lived by the equally memorable aphorism, "It's good to be shifty in a new country" $(S S, 12) .{ }^{19}$ But Hooper's tale of Simon Suggs is not just the record of an odd character performing humorous antics in a peculiar place and time. It ups the ante on Georgia Scenes by inserting an unconventional figure into the running for political office, selling Simon's qualifications as a viable candidate for sheriff to the local voting public. In doing so, Simon Suggs satirizes the campaign biographies of the era. ${ }^{20}$ Yet if Hooper intended to parody the form in order to demonstrate the absurdity of someone like Simon become an elected official, the narrative falls short. Ripe with elements of the carnivalesque in the form of a persistent strain of anti-official play, the narrative is at once tempered and ironized by a genteel narrator somewhat elevated above — though often sidelined by — the characters' vernacular exchanges. Unlike Longstreet's paternalistic wariness toward unmanaged democratic play, Simon Suggs indulges the radical possibilities of democratic play at the expense of national social and political norms.

The narrative sets about the work of dismantling conventional hierarchies that supplement national management in the opening scene when Simon gains his emancipation from Jedidiah, his despotic father. The episode works by deflating Jedidiah's overweening sense of self deriving from a presumption of a cosmopolitan urbanity, a consequence of his travels to the metropolitan city of Augusta. These travels have led Jedidiah to two conclusions: "the one was, that a man who had never been at Augusta, could not know any thing about that city, or any place, or any thing else; the other, that one who had been there must, of necessity, be not only well informed as to all things connected with the city itself, but perfectly au fait upon all subjects whatsoever $(S S, 23)$. The use of elevated language — a conceit that peppers the tale — signals the pending subversion of hierarchies and conventions. In this case, Jedidiah's self-aggrandizement 
exposes him to ridicule (from the reader) and undermines his patriarchal authority (in relation to Simon, who knows how to exploit Jedidiah's inflated ego). Jedidiah agrees to Simon's suggestion to negotiate the rules of a card game and corresponding wager: if Jedidiah wins, he punishes Simon and takes whatever money he is carrying; if Simon wins, he avoids his father's wrath and wins both his freedom and a horse. Under these mutually negotiated terms following the suspension of conventional hierarchies, Simon plays on his father's privileging of extralocal experience at the expense of local concerns, winning the game and his freedom.

This scheme does not, however, empower all equally. As in other tales of Southwestern humor, an African American character receives the violent retribution for the loss or subversion of traditional power relations. Simon's African American co-conspirator and playmate, Bill, interacts with Simon as an equal, frequently contending with him over the rules of their own games. But when Jedidiah catches the young men shirking their work, Bill receives a whipping, which affords Simon time to plot an escape from his father. As Sheila O'Brien notes, such an incident both "reflected and encourage the racist social order." 21 Extending O’Brien's observation, we might see this reification of a social category's order as a kind of desire to reinscribe all social order, which includes the Constitutionally-managed variety. Simon may be able to overturn the level of social order that the story associates with cosmopolitan, if not national, pretensions, but his manifestation of local power is unable to escape the racial order, which acts as a placeholder for the larger social order. In Simon Suggs, not every character has full access to democratic play and thus to self-authorizing political action. Race and gender lines often determine the boundaries of democratic play, acting to stabilize - and thus determine the true limits of - social play. 
Following his emancipation, Simon takes up a new pastime of tricking individuals who take it one step beyond his father's supposed cosmopolitanism and openly declare their investment in national norms. In one instance, Simon takes advantage of an unscrupulous banker who mistakes him for an elected state representative. While sharing a stagecoach ride to Tuscaloosa, the state capital, the banker takes Simon to be a man of authority and influence. "Your election," he assures Simon, in an idiom intended to showcase good breeding, "by the enlightened people of the important county you represent, is ample guaranty to me, that you are a gentleman of the nicest honor, and the most unimpeachable veracity" (SS, 49). As with Simon's father, the banker's pretense to an elevated language signals a misplaced faith in the superiority of supralocal identifications over locally-defined and negotiated positions of power. While he never claims to be an elected official, Simon does nothing to dispel the banker's inference. In consequence, the banker offers him a "loan" to buy future votes in the legislature.

The scene does more than demonstrate Simon's ability to con; it also reveals the banker's interest in controlling the procedural tools of democratic governance. Presuming that Simon's representation occurs far removed from the interests and people he allegedly represents, the banker attempts to take advantage of the distance between government and population, a political ideal asserted by James Madison in Federalist, number 10. Yet the joke is on the banker, along with anyone who assumes the abstractions of federal governance. In the very next scene, Simon enters a barroom occupied by "men of fortune," rich and poor alike, with "a large proportion [being] members of the legislature" (SS, 55). Standing side-by-side with legislative representatives in the tavern, Simon enjoys the social equality that Timothy Gilfoyle identifies in barrooms of this era, which "endowed participants with feelings of liberty and independence while inducing a sense of equality." ${ }^{22}$ Collapsing the distance between representative and 
represented in a space that fostered democratic ideals of liberty and equality, the narrative suggests that national abstractions of the Madisonian variety find little traction in this locale. The tavern depicts a democratic space that is an alternative to the legislature, a space in which elected representatives do not stand in for a community (and thus open to bribes) but instead stand among the members of their community as equals, playfully negotiating the terms of self-rule.

To this point, Simon Suggs has shown little explicit need for collective political action. The Indian Uprising episode puts these alternative formulations to the test. Having exposed the distance between national ideals and local materials in its allusion to Jackson and his biographer, the narrative explores that expanse as it details the response of the local citizenry to the threat of Indian attack: "The yeomanry of the country—-those to whom, as we are annually told, the nation looks with confidence in all her perils - packed up their carts and wagons and 'incontinently' departed for more peaceful regions" (SS, 83). Unlike Longstreet's tales, which affirm the national symbol of the yeomanry while striving to manage any less-than-genteel behavior on their part, Hooper's narrative explicitly distinguishes the illusionary national symbol and its local instantiation.

Further distinctions between national and local scales appear more subtly when the narrative conveys the episode's temporal conditions. Theorists of the nation such as Benedict Anderson and Homi Bhabha have described how the nation is bound together by a simultaneous experience in empty homogeneous time. Hooper's story, however, reveals that, far from a shared national ethos, the local hardly experiences any sort of simultaneity—and thus little sense of imagined community — with other localities. Midway through this episode, the narrative distinguishes local time from any national standard: "It was at an early hour; in fact—speaking according to the chronometrical standard in use at Fort Suggs — not more than "fust-drink time"' 
$(S S, 97)$; later, it conveys the drudgery of life in micro-space metonymic of the local: "time at last began to hang heavily upon the hands of the inmates of Fort Suggs" $(S S, 111)$. Both examples of a localized sense of time are unsynchronized with the progressive temporalities indexed by the opening scene's national allusions. Time is not an abstract measurement that can be translated across wide distances, thus tying together this locality with others and forming a nation; rather, time becomes a marker of certain kinds of activity or inactivity that can only be materialized through actual, experiencing bodies negotiating their lives on immediate terms.

Temporally disconnected from the nation, this locality becomes unmoored from hegemonic norms of national political procedure. Power structures are up for grabs, and Simon, who happens to be at Taylor's store "when the wagon, cart, and, pony loads of the 'badly-scared' mortality [begin] to arrive," stands ready to take advantage. Simon knows something the other do not: "And he enjoyed these [frightened people] to the uttermost now, because he was well informed as to the state of feeling of the Indians, in all the country for ten miles around, and knew there was no danger" $(S S, 85)$. How Simon knows this little fact that escapes the rest of the community (and the federal government) is not disclosed, but his position as intermediary between the whites and the Indians allows him to exploit the community's (and the nineteenthcentury reader's) assumptions about the Indians predicated on national views. Simon craftily assumes leadership over the eighty or so white refugees gathered at the story after a majority agrees to make him captain. As an elected — and not appointed in standard military practicerepresentative, he declares martial law, renames Taylor's store Ft. Suggs, and revels in his new power. In this way, the process seems to reiterate conventional national tropes. Instead of fostering the democratic play that had made him one of his constituents, Simon places himself above the constituents of his sociality and governs in a way that mimics national forms. His 
method of governance, in fact, veers toward despotism when he institutes martial law-Hooper's jab at Andrew Jackson's methods in New Orleans in the War of 1812 - and makes himself a representative of the executive and judiciary: captain, judge, and jury.

This ascendance to power proves short-lived, however, and the narrative quickly reveals Simon's inability to impose national standards on his local community. More importantly it reveals how local community circumvents national impositions, regardless of the variety instituted. At the moment that Simon assumes his despotic role, the democratic play begins. Widow Haycock, who "desired to possess herself of a certain 'plug' of tobacco ... during the watches of the night" (SS, 90), sneaks out of the fortifications and retrieves her supply. Upon her return, she makes some noise, setting off the pickets and causing Simon's incompetent army to fire under the presumption of an attack. In the face of the Widow's unwitting dissidence, Simon maintains control by declaring a drum-head court-martial, an overreaction that parodies the very authority Simon would preserve. What ensues can best be described as a parody of due process.

In preparation for the court-martial, Simon dresses himself in a costume that includes a rusty sword, a pin-cushion turned epaulette, and a handkerchief-sash, a burlesque of formal martial uniform. In the trial itself, Simon's excessive and inaccurate use of legal jargon and constitutional language lampoons the elevated formality of national judicial standards that the rustic and cultural otherness of the local, like Simon's martial costume, renders both ridiculous and ineffectual. In these ways, the narrative implies that mapping national forms of law enforcement upon this local community simply does not work. Simon nevertheless presses on, and he "condems [the Widow] to be baggonetted to deth in one hour from this time, witness our hands and seals" (SS, 104). When the Widow begs for clemency, Simon responds, "I wish ... thar was some way to save her. But ef I was to let her off with a fine, I might be layin' myself 
liable to be tried for my own life" (SS, 107). Simon's verbalized thoughts—along with his odd deferral to a mythic higher judicial authority that is truly nowhere to be found-undercut his attempt to maintain power. Reading this from one direction would suggest that Simon and his ragtag sociality clearly need someone more competent to step in and assume leadership, something like Longstreet's institutions engineering progressive reform. On the other hand, Simon's failure to impose order reflects the narrative's claims regarding the absurdity of overlaying national management upon a locality more amenable to alternative democratic sociality.

Simon's behavior - in this and previous scenes - recalls another literary tradition: the carnivalesque as theorized by Mikhail Bakhtin in Rabelais and His World. In Bakhtin's words, "Rabelais' images have a certain undestroyable nonofficial nature. No dogma, no authoritarianism, no narrow-minded seriousness can coexist with Rabelaisian images." ${ }^{23}$ As the counter to official life, "carnival ... marked the suspension of hierarchical rank, privileges, norms, and prohibitions ... hostile to all that was immortalized and completed." ${ }^{24}$ The breakdown of hierarchies in Rabelais's fiction evokes new types of interaction, spawns new kind of communication, and creates an overall sense of newness in forms, words, and meaningsmaterial that fosters the conditions for more radical instantiations of alternative democratic sociality. ${ }^{25}$ Throughout the Indian Uprising episode, Simon engages in anti-official carnivalesque behavior. On the night of the Widow's tobacco incident, for example, he and his lieutenant enjoy, "with a bottle of bald-face between them, . . . a social game of "six cards, seven up" (SS, 90). Amidst this festive carnivalesque atmosphere, authoritarianism and conventional hierarchies prove unsustainable. 
In what initially appeared to be a new form of despotism, the anti-official carnivalesque works to bring about justice endorsed by all participants: the Widow is spared, and Simon's claim to ruling power is rechanneled back into the sociality. From this point, the narrative describes more good-natured carnivalesque gaming, including "sorties upon ox-wagons ... dollar-pitching, and an endless series of games of 'old sledge;' as well as the occasional exhibition of chuck-a-luck table" ( $S S, 111)$. The formal language is now discarded in favor of the collectively employed vernacular, and the local sociality enjoys a more egalitarian atmosphere. Shortly thereafter, the Indian Uprising episode concludes with a playful engagement at a ballgame between two villages of the allegedly threatening Creeks. The danger is exposed as a complete hoax, and both groups plan good-natured pranks against the other (which, along with the lack of real threat, is a telling comment on race relations between whites and Indians in this locality). Simon's absurdly comical behavior and the evocation of the carnivalesque project a new sense of social living that mocks national overdetermination, calling instead for an investment in the immediacy of local and dialogical engagement. Unlike Longstreet's attempted normalizations of local varieties, Hooper's play on the gap between the local and the national effectively expands the boundaries of the democratic imaginary. Simon Suggs thus unapologetically portrays a group of people self-determinedly—and successfully—engaging in ongoing negotiations of social living according to the localized dictates of democratic play.

\section{LESS PLAYFUL DEMOCRATIC PLAY}

First introduced in 1854, Sut Lovingood made one appearance in Porter's Spirit of the Times before circulating in southern newspapers (with at least one significant exception, which I will address shortly). In 1867, Harris published a collection of twenty-four sketches with the New 
York-based Dick \& Fitzgerald. ${ }^{26}$ In nearly every episode, the educated narrator, George, foregoes the role of the conventional framer and turns the storytelling reins over to Sut's vernacular tongue. What results is a combination of self-aggrandizement, self-deprecation,

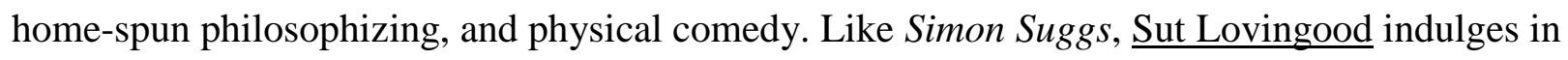
the subversion of traditional hierarchies, preparing the ground for alternative democratic sociality determined by local interests. Yet Sut's methods, which include numerous diatribes against representative figures of authority — elected politicians, law officers, church leaders—and frequent acts of violence, often seem little more than expressions of nihilism. Put another way, Sut Lovingood's subversion tends more toward animalistic anarchy-a deterritorialization of power similar to that articulated by Gilles Deleuze and Felix Guattari-than a functioning radical democracy. Although quite different from Simon Suggs's positive representation of democratic play, Sut Lovingood marks a different point on the spectrum of this tradition's potential to imagine how local actions and social relations might operate outside the normalizing tendencies of the national frame.

Like Simon's, Sut's defiance of arbitrary authority begins at home, where he recognizes from the very start that the hierarchical "law of the father" is fraught with nonsense, especially given his pedigree. In "Sut Lovingood's Dad Acting Horse," the family's plow horse has just died, and rather than buying or stealing a new one, Dad himself plays the role of horse. Excessively faithful to the role, Dad strips naked, chomps on a bridle, bites Sut, and kicks Mam. Mam's rejoinder-"Yu plays hoss better nur yu dus husban"-marks the extent to which this episode upends traditional notions of the familial order. ${ }^{27}$ Subsequently, Dad stomps over a sassafras bush, upsets a hornet's nest, and runs through every possible obstacle before jumping off a cliff into a creek. Through it all, Sut looks on and issues many humorous taunts. Little has 
changed by the time of Dad's second appearance in "Dad's Dog-School." In this episode, Sut's family joins in the attempted training of their young puppy, Sugar. To "make" the pup, Dad has Sut's sister Sall sew him up in a dead bull's hide and instructs Sut to sic the dog on him. Dad again plays his part wholeheartedly. When Sugar's teeth pierce Dad's cowhide costume, he breaks character, drawing a rebuke from Sut. Eventually, Sall intervenes with an axe to break Sugar's hold, taking a bit of flesh from the noses of both Dad and the pup. Having had enough, Mam ends the affair: "Hu ever hearn ove the likes bein dun by the daddy ove a famerly. . . Now jis' quit, an' let that ar blasted roun-headed pup edecate hissef like yer uther childer dus" (SL, 279-80). As in the earlier episode, Mam's comments underscore a prominent theme in both stories: no authority — particularly that based in patriarchy—is natural or unquestionable. Such an idea stands as a valuable precursor for alternative democratic sociality.

This trope - the leveling of patriarchal authority figures - recurs throughout the Lovingood yarns, most often by means of Sut's distinctive strategy of describing these figures in animalistic terms. As Deleuze and Guattari have argued in their study of the fiction of Franz Kafka, the act of becoming-animal enables a dismantling of the Oedipal triangle and parallel triangular relationships of power. In particular, they contend that Kafka's fiction works "to augment and expand Oedipus by adding to it and making a paranoid and perverse use of it[,] ... passing above the shoulders of the father what had really been the question all along: an entire micropolitics of desire, of impasses and escapes." Like Kafka's fiction, these two Sut Lovingood episodes clearly make a paranoid and perverse use of the Oedipal triangle, consequently "opening the impasse, unblocking it. . . But to do this, Oedipus had to be enlarged to the point of absurdity, comedy." 28 This challenge leads to realizations beyond the conventional power structures of the family, as "one discovers behind the familial triangle (father-mother-child) other 
infinitely more active triangles from which the family borrows its power." 29 Texts such as Kafka's fiction and Sut Lovingood most effectively challenge the territorialization of power through the trope of becoming-animal: "to become animal is to participate in movement, to stake out the path of escape in all its positivity." 30

In these terms, we can read Sut Lovingood's recurrence to authority figures becominganimal as providing the local sociality with lines of escape from national containment strategies and making it open to democratic play. "Sut's Daddy Acting Horse" and "Dad's Dog-School" both exaggerate and subvert the entire Oedipal fantasy, largely as a result of Dad's becominganimal. Perhaps because of his marginalized status, Dad's bestial role serves as a playful (if painful) abdication of his representative position of patriarchal authority, creating space for others to participate in the exercise of family authority; conversely, because this tale is told in his unique voice, Sut could be offering his own radical refiguring of patriarchy. Either way, the event opens the door for often-excluded others to participate in the exercise of family authority. Mam's ongoing commentary serves as a jeering chorus exposing the foibles of Dad's schemes, demonstrating her appropriation of that authority as an equal participant in the family's political dynamic. Sut's role in these tales is one of occasional player, close observer, and subsequent narrator. He does not become a substitute for his father, but rather sees past the patriarchal regime as well as other triangles writ large on his community. He will go on to expose those who unjustly derive their power, merited or not (and most often not), from this regime.

By frequently employing this trope of becoming-animal, Sut Lovingood takes a different path than Simon Suggs in challenging national norms and the civic institutions that constrain alternative democratic sociality. As one example, Sut undermines a religious authority when he targets Parson John Bullen, who is known for abusing both Sut and the rest of the community. ${ }^{31}$ 
Sut times his retribution for the moment in a fire-and-brimstone sermon when Bullen introduces "hell-serpents" as his homiletic metaphor, which Sut renders material by releasing a sack-full of lizards in the Parson's pants. Sut then uses a variety of animal metaphors associated with demonic possession to depict Bullen's histrionics, comparing him to an "ole sow" and describing how he "gin his back a good rattlin rub agin the pulpit, like a hog scratches hisself agin a stump" $(S L, 54)$. Eventually, Bullen strips away his clothing, and "he did the . . f fussiest runnin I ever seed, tu be no faster nur hit wer, since dad tried tu outrun the ho'nets" $(S L, 57)$. As with his father, the authority figure becomes animal, at least metaphorically; in doing so, Sut uses his storytelling to expose Bullen as a liar and hypocrite, indelibly aided by this trope of becominganimal. With the explicit reference to Dad's experience of acting horse, Sut effectively binds the stories of these two authority figures together into a single narrative of subversion that works to level the social and political fields. When he uses this trope again in the exposure of the corrupt Sheriff Doltin (the representative law enforcer), calling him at various times an "ole sore-headed bar," "hoss," and a "high preshur snapin turkil" (SL, 259, 260, 273), we know that no corrupt institution is above Sut's recourse.

By these idiosyncratic means, Sut's actions opening his sociality to alternative structures of the political by reducing authority figures (who abuse their powers) to animals. Such a conclusion, however, is hardly unimpeachable. Because of his repeated claims to suffering from being a "durn'd fool," Sut's reliability is always under scrutiny. He might claim that the authority figures act corruptly with respect to the entire community, but his allegations can never be considered incontestable. More troubling, upon subverting abusive authority, Sut Lovingood offers no alternative to the hierarchical relations it overturns. Sut's prefatory dedication—-Ef eny poor misfortinit devil hu's heart is onder a mill-stone, ... hu misfortin's foller fas' an' foller 
faster, ... ef sich a one kin fine a laugh, jis' one ... then I'll thank God that I hes made a book" $(S L, \mathrm{xi})$ — suggests the yarns are merely a compensatory pleasure or escape for those exploited by the conventional structures of social and political authority. Hoping his stories can bring amusement to those who suffer, Sut seemingly longs for a world in which an alternative democratic sociality can thrive outside the nation and the conventions and institutions it endorses. But to find evidence of such local politics at work requires a turn outside the text itself to consider how these stories—and Southwestern humor more broadly—circulated within a literary marketplace.

\section{PRINT CIRCULATING ALTERNATIVE DEMOCRACIES}

Throughout this essay, I have attempted to resituate the point of departure for reading this tradition, primarily in order to read these stories in terms of their focus on local scenarios rather than assuming some sort of nationalist frame, while ever present, is less determining than criticism historically suggests. Humorously subversive and valuably excessive, these tales imagine alternative democratic socialities in which variously realized instantiations of democratic play narrow the gap between individuals and their political agency. Beyond a new critical approach to the internal dynamics of these texts, we might conclude by briefly considering the political work of these texts through their redistribution in print culture. In her account of national compression, Trish Loughran largely depends upon an archive consisting of anti-slavery and abolitionist texts, and no doubt these played a key role in the burgeoning sectionalism —or counter-nationalisms-leading to Civil War. ${ }^{32}$ The circulation of Southwestern humor, however, seems to have had a different effect. Focusing upon authors, readers, and their most notable distributor-Porter's Spirit of the Times - has led to readings of this tradition's 
contributions to a homogeneous (and abstract) national male fraternity. Conversely, I have argued that the rough characters within these stories often exceed the policing action of genteel narrators, suggesting that local conditions may be as important for determining structures of power and decision making as national forms. Moreover, what happens to the political imaginary when texts depicting such people as those represented in Georgia Scenes, Simon Suggs, and Sut Lovingood - people who live lives less determined by nationalist rhetoric and negotiate their own social living in local forms of democratic play—circulate beyond their localities?

One possible answer lies in the prefaces added to these stories as they were transformed from local newspaper articles into collected editions with a larger regional and national audience. In Georgia Scenes, the preface casts doubt on the contents' broader contemporary interest: "The following sketches were written rather in the hope that chance would bring them to light when time would give them an interest, than in the belief that they would afford any interest to the readers of the present day" (GS, xxiii). Published a decade later, Simon Suggs's preface expresses still more doubt about the story's appeal to a national audience: "If what was at first designed, chiefly, to amuse a community unpretending in its tastes, shall amuse the Great Public, the writer will, of course, be gratified" (SS, 6). The preface to Sut Lovingood reveals little interest in such bookish and authoritative norms, even having Sut parody the tradition (as if to take yet another jab at arbitrary authority). When informed that he must have a preface, Sut responds: “Well, ef I must, I must; fur I s'pose the perducktion cud no more show hitsef in publick wifout hit, than a coffin-maker cud wif out black clothes, an' yet what's the use ove either ove em ...?" $(S L$, ix). With similar expressions of anxiety, each preface attempts to dismiss the chance that local humor and literary form could achieve a more heterogeneous audience. Despite their 
success, these authors' doubts suggest that perhaps they did not believe the local communities they represented were, in turn, representable according to national norms.

As another possible clue, I consider two instances of the culture of reprinting that dominated the antebellum publishing scene. ${ }^{33}$ On April 11 and 18, 1845, the (Concord) New Hampshire Patriot printed under the title of "Simon Suggs, the Shifty Man" two succeeding episodes, the ones involving Simon's emancipation from his father. In the April 18 edition, an editorial comment regarding "the following good "un"" reminds readers that this is the second of two installments, and then offers a quick summary of the first episode:

It will be recollected that Simon, then a boy, was caught by his father- --"a hard shell Baptist preacher," in the act of playing "old sledge" with a negro boy named Bill, for which the old man, with a handful of hickory sticks, threatened to take the bark of both of them, and marched them both off to "the Mulberry," the scene of all formal punishment administered during the work hours in the field. It is at "the Mulberry," that the present sketch opens. ${ }^{34}$

As we have seen, this episode depicts Simon gaming his way out of trouble while Bill suffers a cruel beating. What attracted a non-metropolitan New Hampshire reading public to such a tale? It does not seem, given the introductory frame, to intensify sectional difference, as the editors' designation of this "good "un"” implies a sympathetic audience. The decision to print the second of these two episodes one week after the first assumes an interested readership and a taste for such sketches. Certainly a general curiosity for localized flavor in somewhat exotic settings might explain the interest. On the other hand, what might appeal to another local audience is the 
story's attention to the way power is negotiated outside the national apparatus, what I have characterized as alternative democratic sociality.

If this cross-sectional camaraderie is understandable in the somewhat milder 1840s, then a later example proves even more intriguing. On June 8 1861, a trans-regional reprinting occurred when the Los Angeles Star published an excerpt from a full story that had appeared months earlier in the Nashville Union and American. ${ }^{35}$ Buried in the middle of page four, the passage bears the title "Photograph of Lincoln—Read and Laugh, laugh and read—read it again and read it deeper" along with the signature "Sut Lovegood." Excerpted from a three-part story describing how Sut assisted Abraham Lincoln on his journey to Washington DC for his inauguration, the passage features Sut's physical description of Lincoln:

His mouf, His paw, and his footzes am the principil feeters, and his striking pint is the way them air legs ov hisn gets inter his body.... Ov all the darned skeery looking ole casses for a president ever I seed[,] he am decidedly the durndest. . . . I knocked a bullfrog once and druv a nail through his lips inter a post, tied 2 rocks to his hine toes and stuck a darnin needle inter his tail to let out the misture, and lef him thar tu dry. I seed him 2 weeks arterwurds, an when I seed ole Abe I thot hit were an orful retribution come unto me, and that hit were the same frog, only stretched a little longer. ${ }^{36}$

While unflattering portraits of Lincoln were common in the days surrounding his inauguration in publications stretching across the nation, the Los Angeles Star's decision to reprint Sut Lovegood's description - with his nearly-impenetrable dialect and without the rest of the tale- 
seems odd. The reprint could simply reflect sympathy with a Confederate perspective. But the sketch's bestial transformation of the national patriarch might also speak to a broad locally-based desire to undermine the consolidation of national authority over the local and to create a space of democratic play in which individuals take part not simply in making decisions but also in determining the rules by which those decisions are made.

Although difficult to reconstruct motives in the distant past, the two reprints offer alternative frameworks for understanding nineteenth-century scales of affiliation, and for thinking about the national in relation to the local at a time when such a discussion would certainly have redacted another set of scales - the controversy of national versus state sovereignty. As Lloyd Pratt has suggested, traditional assessments of the local as something irretrievably absorbed by the national warrants revisiting. "If the national is thought to follow the local and replace it," Pratt argues, "then this is because history is often thought to have only one track. It follows that in order for the national to realize itself, the local must ipso facto yield to the nation." ${ }^{37}$ Building on Pratt's premise, I suggest approaching these sketches from a local point of view and "reading democratically" offer new possibilities for understanding the negotiation of scales of affiliation and affection. ${ }^{38}$ These reprints disclose little, if any, evidence of state, regional, or sectional identification, but rather cross-regional identifications between localities that do not readily fold into larger scales of region, nation, or section. The idea of an imagined community of any extended dimension seems less likely in these instances than an interest in local autonomy and empowered participation in political life. If the antebellum period marked the expansion of more egalitarian democracy and rhetoric of popular sovereignty—that is, for white, native-born males_-, it would seem that the readers of the Concord and Los 
Angeles newspapers found something in common with humorous tales that deviated from national norms.

Ultimately, the production and distribution of Southwestern humor and its depictions of alternative forms of democratic living contest the often undemocratic work of nationalizing imperatives. Portraying an episode involving an Indian Uprising, the circulating text of Simon Suggs details a group of people engaging in their present moment and negotiating the conflicts of Indian removal in terms of democratic play rather than terms determined by the Constitutionallymanaged nation. Similar moments occur in Georgia Scenes and Sut Lovingood in spite of the former's desire for nationally managed democracy and the latter's failure to fully realize functional alternatives. In each of these fictions, we see the persistence of locally determined democratic play. Rather than assessing these works as aesthetically messy or unruly in form as a condition of the subliterary, as criticism often has, we should see these works as imitating the form of democratic play, of the messy and recursive agency not of a single, coherent, or unified voice but of a messy cacophony of voices unified only in their commitment to a political ideal.

Claremont Graduate University

\section{NOTES}

I must first thank Paul Gilmore and Greg Jackson for reading and commenting upon multiple versions of this essay. I am also grateful to Dana Nelson, Robert Hudspeth, Robert Dawidoff, and Elizabeth Dillon (along with our seminar group at the Futures of American Studies Institute) for their feedback and encouragement.

${ }^{1}$ Johnson Jones Hooper, Adventures of Captain Simon Suggs (1845; reprint, Nashville: J.S. Sanders \& Co., 1993), 82. Further references are to this edition and will be cited parenthetically in the text as $S S$. 
${ }^{2}$ In the last decade, such scholars as Christopher Castiglia, Russ Castronovo, Dana Nelson, Timothy Powell, and Ivy Wilson have effectively traced alternative genealogies of democratic thinking in nineteenth-century literature and culture. See Castiglia, Interior States: Institutional Consciousness and the Inner Life of Democracy in the Antebellum United States (Durham, NC: Duke Univ. Press, 2008); Castronovo and Nelson, eds., Materializing Democracy: Toward A Revitalized Cultural Politics (Durham, NC: Duke Univ. Press, 2002); Powell, Ruthless Democracy: A Multicultural Interpretation of the American Renaissance (Princeton, NJ: Princeton Univ. Press, 2000); and Wilson, Specters of Democracy: Blackness and the Aesthetics of Politics in the Antebellum US (Oxford: Oxford Univ. Press, 2011).

${ }^{3}$ Lynn's claim - that the cordon sanitaire importantly separated the "morally irreproachable Gentleman from the tainted life he described" and signified his distaste for the more egalitarian variations of democracy - have remained highly influential. See Mark Twain and Southwest Humor (Boston: Little, Brown, and Co., 1959), 64. Among the few exceptions, James Justus produced a powerful counterclaim in Fetching the Old Southwest: Humorous Writing from Longstreet to Twain (Columbia: Univ. of Missouri Press, 2004). Notably, Justus contends that these authors "may have resented the raw terms of settling ... but their texts fail to show such resentment." On the contrary, the authors demonstrated such little control that they permitted their subjects "so many speaking opportunities that some [would] hardly shut up" (50).

${ }^{4}$ For the significant roles of transportation and communications, see Daniel Walker Howe, What Hath God Wrought: The Transformation of America, 1815-1848 (Oxford: Oxford Univ. Press, 2007). For the impact of the new market economy, see Charles Sellers, The Market Revolution: Jacksonian America, 1815-1846 (New York: Oxford Univ. press, 1991). For Porter's Spirit of the Times, see Norris W. Yates, William T. Porter and the "Spirit of the Times": A Study of the Big Bear School of Humor (Baton Rouge: Louisiana State Univ. Press, 1998).

${ }^{5}$ See Dana D. Nelson, National Manhood: Capitalist Citizenship and the Imagined Fraternity of White Men (Durham, NC: Duke Univ. Press, 1998).

${ }^{6}$ Examples include Terry Bouton, Taming America: "The People," the Founders, and the Troubled Ending of the American Revolution (Oxford: Oxford Univ. Press, 2007); and Woody Holton, Unruly Americans and the Origins of the Constitution (New York: Hill and Wang, 2007).

${ }^{7}$ Notable exceptions include Ronald P. Formisano, For the People: American Populist Movements from the Revolution to the 1850s (Chapel Hill: Univ. of North Carolina Press, 2008); Laura Edwards, The People and Their Peace: Legal Culture and the Transformation of Inequality in the Post-Revolutionary South (Chapel Hill: Univ. of North Carolina Press, 2009); and William J. Novak, The People's Welfare: Law and Regulation in Nineteenth-Century America (Chapel Hill: Univ. of North Carolina Press, 1996).

8 Trish Loughran, The Republic in Print: Print Culture in the Age of US Nation Building, 17701870 (New York: Columbia Univ. Press, 2007), 345.

${ }^{9}$ Hutchison has asserted the need for recognizing the transnational nature of the late antebellum and Civil War periods, especially for critical readings of cultural objects. See "Whistling 'Dixie' for the Union (Nation, Anthem, Revision)" American Literary History 19 (fall 2007): 603-628. For other competing nationalisms of the nineteenth century, see Levine, Dislocating Race and 
Nation: Episodes in Nineteenth-Century American Literary Nationalism (Chapel Hill: Univ. of North Carolina Press, 2008). For connections between print culture and nationalism, see Benedict Anderson, Imagined Communities: Reflections on the Origin and Spread of Nationalism (1983; rev. ed. London: Verso, 2006).

${ }^{10}$ Dana D. Nelson, "ConsterNation," in Futures of American Studies, eds. Donald E. Pease and Robyn Wiegman (Durham, NC: Duke Univ. Press, 1998), 560.

${ }^{11}$ As one recalibration of scale sensitive to this problem, transnational critiques have circumvented the logical horizons of the nation, helping scholars think about the US in global networks. This essay builds off these global paradigms, yet inverts them back on the US nation.

${ }^{12}$ Castiglia, Interior States, 1.

${ }^{13}$ Quoted in David Rachels, Augustus Baldwin Longstreet's Georgia Scenes Completed (Athens: Univ. of Georgia Press, 1998), xlviii.

${ }^{14}$ Augustus Baldwin Longstreet, Georgia Scenes (1835; reprint, Nashville: J. S. Sanders \& Co., 1992), xxiv. Further references are to this edition and will be cited parenthetically as $G S$.

${ }^{15}$ Longstreet employs two narrators, Lyman Hall and Abram Baldwin, names shared by two of the most famous political figures in Georgia's early national history. Hall signed the Declaration of Independence. Baldwin was one of Georgia's first Congressmen following the ratification of the Constitution, serving as both Representative and Senator until his death in 1807.

${ }^{16}$ According to Castiglia, "institutionalism not only made a democratic now nearly impossible to conceive, it assisted in the divisions of types of people depending on whether they were oriented toward the future (biologically and ideologically reproductive) or the past (those 'stuck' in their memories by an unproductive nostalgia or melancholy)" (Interior States, 5). This latter typological orientation aligns with the narrative's temporal register.

${ }^{17}$ Several scholars have attempted to define the structural order. James Meriwether argues for unity in the theme of human progress in need of civilizing norms such as law and order (“Augustus Baldwin Longstreet: Realist and Artist," Mississippi Quarterly 35 [fall 1982]: 35164.). Keith Newlin finds structure in the oscillating targets of satire between upper and lower classes ("Georgia Scenes: The Satiric Artistry of Augustus Baldwin Longstreet," Mississippi Quarterly 41 [winter 1987]: 21-37). James Kibler cites Baldwin's failure to genuinely engage with the various strains of Georgia society while Hall successfully moves from genteel and disconnected critic to gaining acceptance by all ranks of society ( $G S$, "Introduction," vii-xxii). Each claim is viable, but the range suggests that imposing some kind of structure is a critical gesture - something like national management - that fails to contain excesses. Scott Romine offers an assessment that keeps in play the dynamics I have been tracing, but ultimately suggests that "at the heart of Longstreet's narrative lies, essentially, a discourse of colonization through which those previously external, alien, and chaotic backwoods communities are subsumed within the hegemonic order" (The Narrative Forms of Southern Community [Baton Rouge: Lousiana State Univ. Press, 1999], 25). My only exception to Romine's conclusion lies in this subsumption to the hegemonic order; this might have proven historically true, but I stop short of this teleological conclusion to keep the contingency of the scenes in play.

${ }^{18}$ W. Stanley Hoole, Alias Simon Suggs: The Life and Times of Johnson Jones Hooper (Westport, CT: Greenwood Press, 1970), 21. 
${ }^{19}$ Hooper's early writings harnessed the attention of William T. Porter, who published Hooper's first story, "Taking the Census," in 1843. Splitting time between responsibilities as newspaper editor and circuit-riding lawyer, Hooper hit his literary stride in December 1844 with the publication of his first story featuring Simon Suggs. By the end of the following summer, the Philadelphia firm Carey \& Hart published the first edition of Some Adventures of Simon Suggs, which sold quickly, requiring eleven subsequent editions over the next decade.

${ }^{20}$ For Kenneth Lynn, this form betrayed Hooper's Whig-oriented disdain for the crudity of Jacksonian democracy, allowing overt jabs at Andrew Jackson and his administration as well as criticizing Democratic party politics (Mark Twain and Southwest Humor, 78-85). See also Robert Hopkins, "Simon Suggs: A Burlesque Campaign Biography," American Quarterly 15 (autumn 1963): 459-463.

${ }^{21}$ Sheila R. O’Brien, “Writing with a Forked Pen: Racial Dynamics and Johnson Jones Hooper's Twin Tale of Swindling Indians," American Studies 35 (fall 1994): 95.

22 Timothy Gilfoyle, City of Eros: New York City, Prostitution, and the Commercialization of Sex, 1790-1920 (New York: W.W. Norton, 1992), 81.

${ }^{23}$ Mikhail Bakhtin, Rabelais and His World, trans. Hélène Iswolsky (Bloomington: Indiana Univ. Press, 1984), 3.

24 Ibid., 10.

${ }^{25}$ Milton Rickels has been one of the few to connect Bakhtin's work on the carnivalesque with Southwestern humor. See "The Grotesque Body of Southwestern Humor," Critical Essays on American Humor, eds. William Bedford Clark and W. Craig Turner (Boston: Hall, 1984).

${ }^{26}$ Sut's most common appearances prior to the 1867 collection occurred in the Nashville Union and American. Among several uncollected tales were three in which Sut escorts Abraham Lincoln from Illinois to his inauguration.

${ }^{27}$ George Washington Harris, Sut Lovingood Yarns (1867; reprint, Memphis: St. Lukes Press, 1987), 23. Further references are to this edition and will be cited parenthetically in the text as $S L$.

${ }^{28}$ Gilles Deleuze and Felix Guattari, Kafka: Toward a Minor Literature, trans. Dana Polan (Minneapolis: Univ. of Minnesota Press, 1986), 10.

29 Ibid., 11.

${ }^{30}$ Ibid., 13.

${ }^{31}$ Bullen's most offensive abuse of power occurs when he catches Sut and an unnamed woman in a compromising position, then informs his consort's mother after assuring the girl that he would keep the matter to himself. Yet this is just one of many affronts. Sut hints at other offenses committed by Bullen and his Hard Shell Baptist cronies, citing their tendency to commit misdeeds and use Sut as a scapegoat: "all git drunk, an' skeer thar fool sefs ni ontu deth, an' then lay hit ontu me" $(S L, 49)$.

${ }^{32}$ See Loughran, The Republic in Print, 303-361.

${ }^{33}$ See Meredith McGill, American Literature and the Culture of Reprinting, 1834-1853 (Philadelphia: Univ. of Pennsylvania Press, 2003). 
${ }^{34}$ New Hampshire Patriot, April 18, 1845.

${ }^{35}$ Nashville Union and American, February 28, 1861.

${ }^{36}$ Los Angeles Star, June 8, 1861.

${ }^{37}$ See Lloyd Pratt, Archives of American Time: Literature and Modernity in the Nineteenth Century_(Philadelphia: Univ. of Pennsylvania Press, 2009), 131. Of note, Pratt's study includes a chapter on Southwestern humor, in which he takes Lynn's cordon sanitaire theory as a given, something that this essay has directly challenged.

${ }^{38}$ Nick Bromell has posited "reading democratically" as a critical venture that uses past literature to help us better understand the challenges and potential for democracy in our current moment. See "Reading Democratically: Pedagogies of Difference and Practices of Listening in The House of Mirth and Passing," American Literature 81 (June 2009): 283. 